\title{
事象関連電位（ERP）を用いた入浴の精神疲労回復効果 の評価"
}

\section{植竹篤志**, 村田厚生 $* * *$}

\begin{abstract}
The effects of bathing on recovery from mental fatigue were verified using the latency and the amplitude of event related potential (ERP). The effect of the lukewarm bathing that is regarded as effective for the recovery from mental fatigue was examined. The difference of the degree of recovery was compared between the bathing and non-bathing conditions. As a result, the degree of recovery of both P 300 amplitude and latency tended to be greater for the bathing condition than for the non-bathing condition. The degree of recovery was defined as the changes of P 300 latency and amplitude after $60 \mathrm{~min}$ from the completion of an experimental task as compared to those immediately after the completion of the task. The rating score of mental fatigue after $60 \mathrm{~min}$ from the end of the task decreased more prominently in the bathing condition than in the non-bathing condition. In conclusion, it was verified that the lukewarm bathing worked for recovering from mental fatigue.
\end{abstract}

入浴の精神的な疲労回復効果を検証するため, 事象関連電位の潜時と振幅で評価する手法を適用し た. その手法を用い, 精神疲労の回復に有効であると言われている微温浴の効果を実験的に検証し た. 計算作業を行い精神的な疲労を蓄積させたのち, 疲労回復手段として, 入浴を行った場合と安静 のみの場合を比較検討した. 作業終了直後に対する作業終了 60 分後の P 300 振幅と潜時の比率を疲 労回復の程度と定義し, 入浴条件と非入浴条件でこれを比較した結果, 入浴条件では非入浴条件に比 べ, 有意に振幅の比率が大きくなり，潜時の比率も減少傾向があった。また，主観評価結果からも入 浴条件では精神疲労感が有意に減少しており，微温浴には精神疲労を回復する効果があると考えられ た.

(キーワード : 入浴, 精神疲労, 事象関連電位, 計算作業)

\section{1. はじめに}

現代では，入浴は単に身体を清潔にするという行為 だけでなく，身体をリラックスさせ 1 日の疲れをとる という目的も非常に重要視されてきている1).入浴の 効果は温熱, 水圧, 浮力の物理作用と心理的作用によ って得られる2). 入浴に関する研究に目を向けてみる

* 受付 $: 2001$ 年 1 月 22 日 受理：2002 年 1 月 18 日

** 積水化学工業(侏筑波研究所

Tsukuba Reserch Laboratories, Sekisui Chemical Co., LTD.

*** 広島市立大学情報科学部

Faculty of Information Sciences, Hiroshima City University
と, 古くから医学的な見地やリハビリの観点から, 温 熱に対する生体反応の研究が多く行われている ${ }^{3 \sim 7)}$. また, 入浴の効果が高い一方で, 浴室内での事故も多 いことから，温熱負担に対する安全性の観点からの研 究も多い ${ }^{8 \sim 11)}$. 疲労回復という面でみてみると, 入浴 剂の疲労回復効果および筋疲労に対する研究は非常に 多く実施されている1,9,12 14). しかし，精神的な作用 にかかわるものになると意外に研究例が少なく, リラ ックス ${ }^{15)}$ や脱ストレス作用 ${ }^{16)}$ に関するものが若干見 受けられる程度である. 精神疲労の回復効果の評価と いう観点では, 主観やフリッカーなどで計測された研 究はあるが17), その効果が言われつつも実際に生理的 に検証された例は非常に少ない。

一方, 我々は精神的な疲労状態が認知処理の時間的 側面, 処理活動の強度・量的側面に影響を与える因子 
であるとの仮説に基づき, 誘発脳波の一種である事象 関連電位（ERP）による精神疲労評価を検討してき た。 その結果, 精神疲労の評価に対して事象関連電位 の P 300 の振幅や潜時が有効であることを見いだして きた ${ }^{18,19)}$. 精神的な疲労の発現に伴い, 脳幹網様体の 制御によりブレーキ系が有意になり ${ }^{20)}$, 大脳新皮質の 活動が低下するとともに, 認知情報処理時間の遅れが 起こった結果, P 300 潜時の延長, 振幅の低下が起こ ると考えられる.これらの知見に基づき，精神疲労の 有効な回復手段のひとつと考えられる入浴を題材とし て取り上げ, 入浴の疲労回復効果を被験者の生理・心 理からどのように捉えることができるのかを，P 300 潜時・振幅および心理的な疲労評価に基づいて検討し た.

\section{2. 実験方法}

\section{2-1. 被験者}

健康な男性 4 名（平均 27.3 歳土3.63）女性 2 名

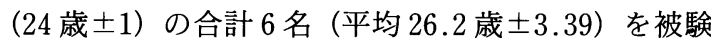
者とした。各被験者に入浴条件，非入浴条件の両方を 行ってもらう被験者内計画とした。実験には 1 人 1 条 件につき 180 分を要した。

\section{2-2. 作業課題}

精神疲労蓄積のための課題としては, ディスプレイ （VDT）上に提示される 3 析の数字 2 組を暗算により 加算し, キーボードにより回答する計算作業を 120 分 間 (30 分 $\times 4$ 試行) 行わせた. 被験者にはできるだけ 早く正確に作業を遂行するよう教示した。実験時刻帯 は $13 ： 30 \sim 16 ： 30$ とした. 制御には PC 9801-RA を 用いた。

\section{2-3. 生理計測項目}

電極位置は国際 10-20 式法に基づき, $\mathrm{Fz}, \mathrm{Cz}, \mathrm{Pz}$ 3 部位から, 両耳架電極をショートさせたものをレフ アレンスとした単極誘導で導出し, 正中線上中心部 （C 3）よりボディアースをとった. 眼球運動による) イズを除去するために，眼球運動に伴うまぶたの動き を計測するため簡易的に左眼球斜め下に電極を配置 し，リジェクトレベルを $140 \mu \mathrm{V}$ に設定した。

\section{2-3-1. 事象関連電位}

提示刺激は Oddball 課題を採用した。装着したへ ッドホンから出る $1,500 \mathrm{~ms} \pm 300 \mathrm{~ms}$ のランダムな間 隔のスタンダード刺激として $1,000 \mathrm{~Hz}$ (出現率 $80 \%$ ), ターゲット刺激として $2,000 \mathrm{~Hz}$ (出現率 20\%）のトーンバースト（65db）を提示した. ター ゲット刺激に対してボタン押しを行う課題を課した。

分析区間は刺激提示にあわせてトリガー信号をか け, 刺激前 $160 \mathrm{~ms}$ から刺激後 $640 \mathrm{~ms}$ の $800 \mathrm{~ms}$ を 800 ポイントとして, ターゲット刺激提示後の事象関 連電位を 30 回加算した.これをもとにP 300 の頂点 潜時, 振幅を計測した。

\section{2-3-2. 自発脸波}

安静閉眼時（5 分）の自発脳波を計測した。計測は シグナルプロセッサ（日本電気三栄：DP 1100）付属 のヘッドアンプを介し，データレコーダ（ティアッ ク：RD-200 T) に記録した. 分析はデータレコーダ より再生した原波形を, シグナルプロセッサ (DP 1100 : 日本電気三栄) およびパッケージプログ ラム (日本電気三栄) を用いて, 高速フーリエ変換 (5 秒間を 1,024 ポイントに分割し処理したものを, 30 回加算）によってパワースペクトラムを算出した. これをもとに, (1)ピーク周波数前後 $\pm 1.0 \mathrm{~Hz}$ のパワ 一量, (2) $\alpha$ 波帯域 $(8 \sim 13 \mathrm{~Hz})$ のパワー量をもとめ た.

\section{2-4． 心理計測項目}

\section{2-4-1. 精神疲労感評価表}

精神疲労に関する質問表を，作業前・作業後・入 浴/休顋後に使用した.この精神疲労評価表は以前に 独自に開発したもので, 主成分分析の結果, 精神疲労 に対しては 6 項目の言葉で構成されている ${ }^{21)}$. 各言葉 は図 1 に示すように 5 段階で評価するスケールを採用 した。精神疲労スコアを算出するときは，スケールの 各段階に 1 から 5 までの数字を割り当てその項目の点 数とし， 6 項目の平均点を算出することによって求め た.

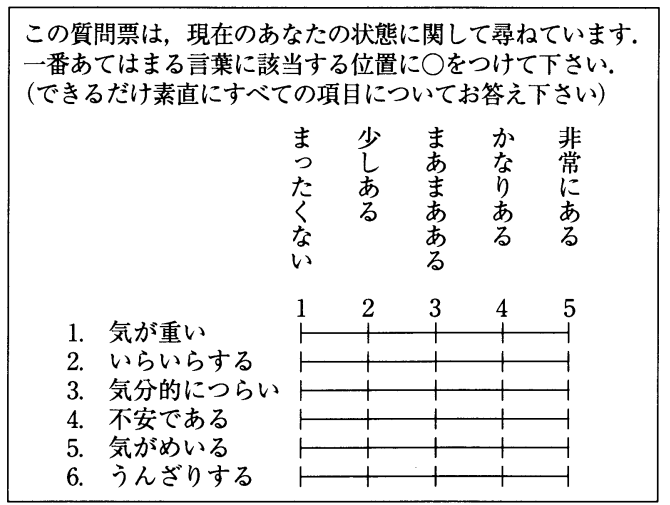

図 1 精神疲労感評価シート

Fig. 1 Subjective evaluation sheet of mental fatigue. 


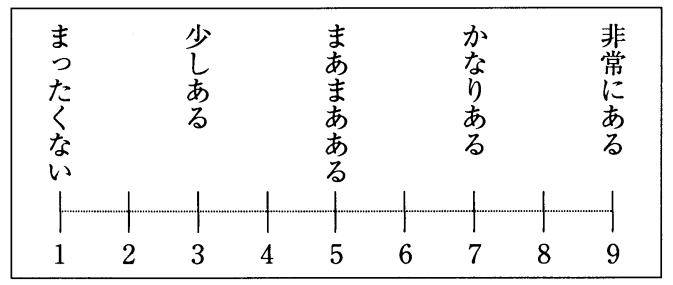

図 2 リラックス感評価スケール

Fig. 2 Relaxation evaluation scale.

\section{2-4-2. リラックス感}

被験者のリラックス感を調べるために，9段階評価 の質問紙を用いた（図 2 参照)。

\section{2-5. 使用浴槽・入浴方法}

電磁シールドルーム内に独自に作成した姿勢可変型 浴槽を使用した ${ }^{22)}$.この浴槽は座位入浴から寝湯まで 姿勢が変更できる特徴を持つ、入浴条件は精神疲労が 回復しやすいとされる微温浴での寝湯を採用した。微 温浴には自律神経系の副交感神経を優位にさせ，体の 緊張をとる鎮静作用がある ${ }^{2), 23)}$. 寝湯の姿勢も副交感 神経を有意にする効果があると考えられる，入浴時間 は最長 15 分までを限度に被験者の自由とし, 精神的 な疲れがとれたと感じた時点で出浴してもらった。こ れは被験者が疲労回復したという感覚を重視したため である。なお, 入浴は湯に浸かるのみとし, 洗体や洗 髮は行わない条件とした。浴室, 脱衣室の気温は $25^{\circ} \mathrm{C}$ ，湯温は $38^{\circ} \mathrm{C}$ とた。

\section{2-6. 実験手順}

図 3 に今回行った実験の手順を示す．作業負荷前の 測定として, 最初に精神疲労感, リラックス感, 覚醒 感の主観評価を行い, 続いて事象関連電位と自発脳波 計測を実施した。その後, 2 時間の暗算作業を連続で 行った後, 再び同様な手法にて, 主観計測と脳波計測 を行った. 疲労回復手段としては, 入浴を行ったケー ス（入浴条件）と入浴を行わず安静にしたケース（非 入浴条件）の二つを実施した. 入浴の場合では入浴時 間とその後の休㮩時間の合計が 60 分になるように, また, 安静のみの非入浴条件ではソファーでの安楽姿 勢とした休息を 60 分間行い, その後, 主観, 生理計 測を行った。入浴時と安静時の姿勢は厳密には異なる が, 双方の疲労回復効果を比較できるように, それぞ れの特徵を生かしよく用いられている姿勢をそのまま 使用した. 疲労回復手段, 経過時間ともに被験者内要 因である。ただし，入浴条件と，非入浴条件の実験は それぞれ異なる日に設定した。

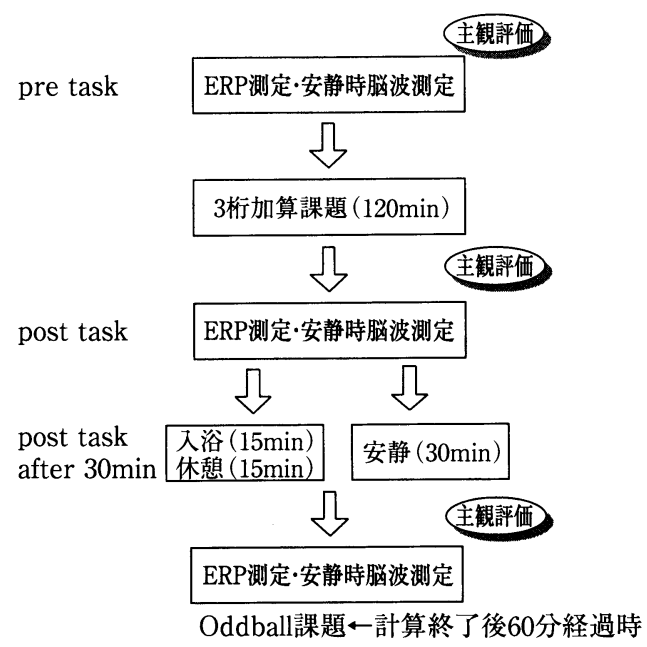

図 3 実験プロトコル

Fig. 3 Experiment protocol.

\section{3. 実験結果}

\section{3-1． 生理計測項目}

\section{3-1-1． 事象関連電位（P 300 潜時, 振幅）}

図 4, 図 5 は，それぞれ入浴条件，非入浴条件（被 験者 Z) の作業前・作業後・作業終了 60 分経過後に 計測した事象関連電位の加算波形である.ターゲット 刺激提示前 $160 \mathrm{~ms}$ から提示後 $640 \mathrm{~ms}$ までを加算対 象としている。図中更はターゲット刺激提示時を示 す. 入浴条件，非入浴条件ともに，負荷後では負荷前 に比べ, $300 \mathrm{~ms}$ 付近での陽性電位（P 300）の頂点潜 時の延長および振幅の減少が認められた。また，負荷 終了 60 分後において, 入浴条件では P 300 潜時の短 縮と振幅の増大が認められ, 非入浴条件では P 300 の 振幅の減少が認められた。

表 1 亿作業開始前と作業終了後の実験結果をまとめ た．表中には ERP の潜時，振幅，自発脳波の $\alpha$ 波パ ワー, ピーク周波数 $1 \mathrm{~Hz}$ のパワーおよび主観評価 の精神疲労感得点, リラックス感得点をあわせて示し てある.P 300 振幅，潜時に関してはこれまでの検討 とほほ同様の結果が得られた ${ }^{18,19)}$. すなわち，作業経 過に伴い P 300 の潜時は延長し, 振幅は減少した。こ の傾向を確認するために，時間経過（作業前と作業 後) と作業終了後の疲労回復法（入浴条件と非入浴条 件）を被験者内要因とする繰り返しのある 2 元配置の 分散分析を実施した。潜時に関しては，疲労回復法 （入浴条件と非入浴条件）では，有意な差は認められ 


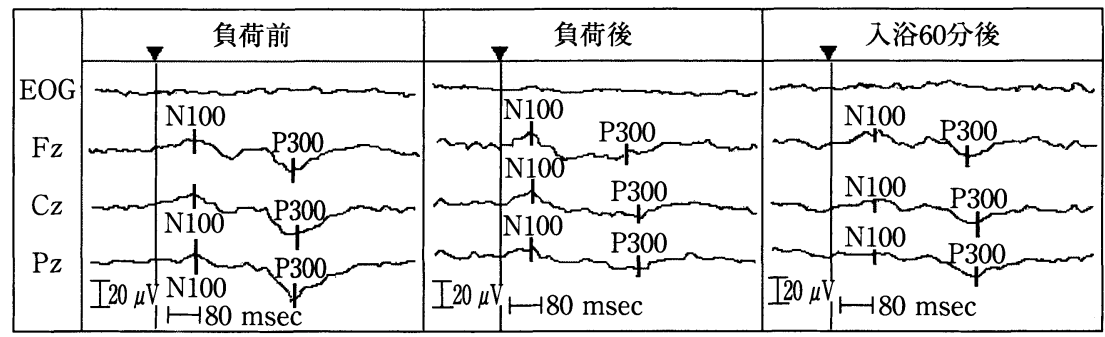

図 4 ターゲット刺激提示後の加算波形（入浴条件：被験者 $\mathrm{z}$ )

Fig. 4 ERP waveform for rare stimuli (Bathing condition : subject $z$ ).

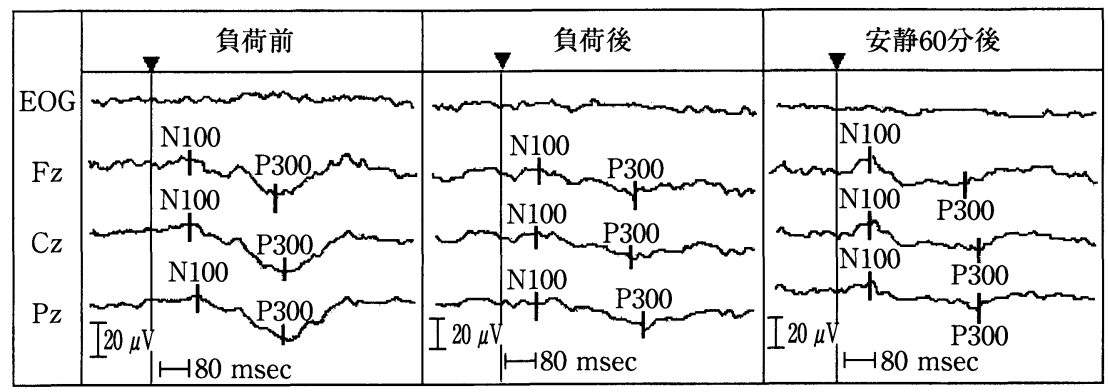

図 5 ターゲット刺激提示後の加算波形（非入浴条件：被験者 $\mathrm{z}$ )

Fig. 5 ERP waveform for rare stimuli (rest condition: subject $z$ )

表 1 入浴条件と非入浴条件での作業前後の P 300 振幅と潜時, ピーク周波数前後士 $1 \mathrm{~Hz}$ のパワー, 主観評価値 (精神疲労感, リラックス感) の比較 (平均値士標準偏差)

Tab. 1 Change of P 300 latency and amplitude, EEG power and subjective rating of mental fatigue and relaxetion between pre-task and post-task (mean \pm s.d)

\begin{tabular}{|c|c|c|c|c|c|c|c|}
\hline \multirow{2}{*}{\multicolumn{2}{|c|}{ 疲労回復条件 }} & \multicolumn{2}{|c|}{ ERP } & \multicolumn{2}{|c|}{ 自発脳波 } & \multicolumn{2}{|c|}{ 主観評価 } \\
\hline & & 潜 時 & 振＼cjkstart幅 & ピーク周波数 & $\alpha$ 波 & 精神疲労感 & リラックス感 \\
\hline \multirow{2}{*}{ 入 浴 } & 作業前 & $316.00 \pm 35.16$ & $13.50 \pm 2.42$ & $287.31 \pm 124.04$ & $450.60 \pm 145.77$ & $13.17 \pm 3.98$ & $4.17 \pm 0.90$ \\
\hline & 作業後 & $330.17 \pm 31.50$ & $8.41 \pm 1.21$ & $249.55 \pm 95.47$ & $438.48 \pm 163.78$ & $19.67 \pm 4.57$ & $3.00 \pm 1.41$ \\
\hline \multirow{2}{*}{ 非入浴 } & 作業前 & $313.33 \pm 19.70$ & $11.20 \pm 2.18$ & $345.64 \pm 205.60$ & $492.65 \pm 264.61$ & $13.83 \pm 4.95$ & $4.83 \pm 0.37$ \\
\hline & 作業後 & $327.67 \pm 23.89$ & $9.24 \pm 2.26$ & $230.21 \pm 87.37$ & $403.96 \pm 177.10$ & $19.42 \pm 3.83$ & $3.17 \pm 1.57$ \\
\hline
\end{tabular}

なかったが，時間経過の要因に関しては有意差が認め られた $(\mathrm{Fz}: F(1,5)=11.401, p<0.01, \mathrm{Cz}: F(1,5)$ $=19.494, \mathrm{Pz}: F(1,5)=6.695, p<0.05)$. 振幅に関し ても, 疲労回復法では有意な差は認められなかった。 時間経過の要因に関しては, 部位 $\mathrm{Cz}$ のみにおいて有 意差が認められた $(F(1,5)=6.747, p<0.05)$. 以上 のように，振幅に関しては，作業後に有意に低下する 傾向が認められ，入浴条件と非入浴条件で作業前と作 業後の值に差は認められなかった。また，潜時に関し ては, 作業後に有意に延長する傾向が認められ, 両疲 労回復法で作業前と作業後の值に差はなかった。すな わち, 入浴条件と非入浴条件で作業後に潜時, 振幅と
もに同程度に機能低下したものと判断できる。

入浴条件と非入浴条件で作業後に同じ程度の機能低 下が生じていることから, 疲労回復手段を講じた後の 疲労回復効果を両条件で適切に比較できると考えられ る.ここでは作業終了後の值を 1 として作業終了から 60 分経過後の值を比率（これを疲労回復の程度と呼 ぶ）で示すことによって疲労回復効果を比較した（表 2 参照). 両疲労回復法での疲労回復の程度 (比率) を Wilcoxonのノンパラメトリック検定によって比較 した，潜時に関しては，入浴条件のほうが非入浴条件 よりも比率は小さい值を示したが，検定の結果いずれ の $\mathrm{C} z$ 部位においてのみ有意差が認められた $(\mathrm{Fz}: z$ 
表 2 入浴条件と非入浴条件での疲労回復程度の比較 (平均值士標準偏差)

(作業終了直後の值に対する 60 分経過後の值の比率)

Tab. 2 Comparison of the degree of recovery from fatigue between bathing and non-bathing condition (mean \pm s.d).

\begin{tabular}{c|c|c|c|c|c|c}
\hline \multirow{2}{*}{ 疲労回復条件 } & \multicolumn{2}{|c|}{$\mathrm{ERP}$} & \multicolumn{2}{c|}{ 自発脳波 } & \multicolumn{2}{c}{ 主観評価 } \\
\cline { 2 - 7 } & 潜 時 & 振 幅 & ピーク周波数 & $\alpha$ 波 & 精神疲労感 & リラックス感 \\
\hline 入 浴 & $0.92 \pm 0.03$ & $1.32 \pm 0.19$ & $1.49 \pm 0.47$ & $1.20 \pm 0.36$ & $0.61 \pm 0.10$ & $2.33 \pm 0.52$ \\
\hline 非入浴 & $1.00 \pm 0.04$ & $1.05 \pm 0.12$ & $1.56 \pm 0.45$ & $1.15 \pm 0.20$ & $0.92 \pm 0.12$ & $1.85 \pm 1.01$ \\
\hline
\end{tabular}

$=-2.084, p<0.05)$. 入浴条件のほうが, 潜時の短 縮傾向が強く, 疲労回復効果が認められた. 同様の検 定の結果, 振幅に関しては, 入浴条件のほうが比率が 高くなり回復傾向が頻著であった．潜時とは異なり三 つの部位いずれに関しても有意差が認められた $(\mathrm{Fz}$ : $z=-2.371, p<0.05, \mathrm{Cz}: z=-2.197, p<0.05, \mathrm{Pz}:$ $z=-2.371, p<0.05)$. 本論文の範囲では, 潜時より も振幅のほうが入浴による精神神経的な回復状態を, 特に認知情報処理の深さの観点からより鋭敏に反映す る可能性が高いと判断できる.

\section{3-1-2. 自発脸波}

$\alpha$ 帯域のパワーとピーク周波数前後 $\pm 1 \mathrm{~Hz}$ のパワ 一に関しても事象関連電位と同様の解析を実施した。 時間経過（作業前と作業後）と作業終了後の疲労回復 法 (入浴条件と非入浴条件) を被験者内要因とする繰 り返しのある 2 元配置の分散分析の結果, 両指標とも に，いずれの要因に関しても有意差は認められなかっ た. ただし, 作業後にピーク周波数前後 $\pm 1 \mathrm{~Hz}$ のパ ワー, $\alpha$ 帯域のパワーのいずれも低下していく傾向を 示した. 事象関連電位と同様の比率を求めて, Wilcoxonのノンパラメトリック検定によって入浴条件 と非入浴条件を比較した結果，いずれの指標に関して も有意差は認められなかった (表 2 参照).

\section{3-2. 心理項目}

\section{3-2-1. 「精神疲労感」得点}

表 1 にみられるように精神疲労感は入浴条件, 非入 浴条件ともに増加した. 条件間での差は分散分析の結 果確認できなかった。作業終了後は表 2 にみられるよ うに, 入浴条件, 非入浴条件で回復傾向がみられた。

Friedman のノンパラメトリック検定を用いて, 入 浴条件と作業経過時間で精神疲労感得点に差があるか どうかを比較した結果, 入浴条件と作業経過時間のい ずれの要因でも有意差が認められた $\left(\chi^{2}(5)=12.662\right.$, $p<0.05)$. 入浴条件での 60 分経過後の「精神疲労感 得点」が最も低い得点であった。この結果からも, P 300 の振幅と潜時に関する解析結果と同様, 入浴条
件での疲労回復効果が示唆された.

\section{3-2-2. 「リラックス感」得点}

「精神疲労感」得点と同様に, Friedmanのノンパ ラメトリック検定を用いて，入浴条件と作業経過時間 で精神疲労感得点に差があるかどうかを比較した結 果, 有意差が認められ $\left(\chi^{2}(5)=21.69, p<0.01\right)$, 入 浴条件での 60 分経過後の「リラックス感」得点が最 も高かった. 入浴条件での疲労回復効果が示唆され る.

\section{4. 考 察}

\section{4-1. 計算作業が生理・心理指標へ及ぼす影響 について}

事象関連電位の振幅, 潜時は計算作業終了後に, そ れぞれ減少，延長する傾向が観察された。これは今ま でに我々が観察してきた結果とほほ同じである ${ }^{18,19}$. 精神疲労感と連動して変化をする事象関連電位の振 幅, 潜時がそのインデックスとなる可能性がここでも 示された. P 300 潜時は刺激の入力から評価完了まで にかかる総合的な時間（刺激の符号化，弁別，記憶と の照合，意志決定）を反映する指標と考えられてお $\eta^{24,25)}$, 計算作業による疲労蓄積が刺激評価時間の遅 れとなって現れたことが示唆された。また，沖田 ${ }^{26)}$ がまとめているように，P 300 振幅は処理の深さや注 意（情報処理容量）と関連が深いとの知見があり, 計 算作業による疲労蓄積が処理の深さ・強度の低減, 注 意の低下を引き起こしたことが示唆された．また，入 浴条件と非入浴条件のいずれにおいても，作業前後の 值はほほ同じで, 作業後に同程度の機能低下が生じて いることから, 両条件で疲労回復手段を講じた後の効 果を一様に比較できると判断できる.

計算作業前後で得られた心理評価からも，120 分間 の計算作業が,「精神疲労感」を顕著に増大させるこ とがわかった。計算作業により精神的な疲労が徐々に 蓄積し，ゆとりがなくなってくる状況に陥っているも 
のと推察される.

一方, 通常の脳波分析に関しては入浴後や安静後等 の休息後では, 作業直後に比べ $\alpha$ 波のパワーゃピー ク周波数 $\pm 1.0 \mathrm{~Hz}$ のパワーが増加する傾向が認めら れたが, 事象関連電位のように統計的な有意差は検出 されなかった。このことから精神疲労のインデックス としては認知情報処理過程の処理時間や処理の深さを 反映すると考えられている事象関連電位のほうが，精 神疲労に対する検出力が高いと考えられる。

\section{4-2． 作業終了後の入浴の効果について}

統計分析の結果から, 入浴条件では, 作業終了直後 から作業終了 60 分の時点で, 「精神疲労感」を低減さ せることが確認された。 入浴条件と非入浴条件のデー 夕を比較してみると, 作業終了直後から休息後の精神 疲労感の変化量は有意に入浴条件のほうが大きかっ た。また，「リラックス感」についても，入浴条件に おいて休悡後に得点が有意に増加する傾向が見られ た。 入浴条件ではそれに加えさらに，入浴による温熱 などの効果も相まって, 特に疲労回復感とリラックス 感が有意に改善されたと考えられる.

このことは生理指標の上からも検証することができ る. 精神疲労の指標と考えている事象関連電位の潜時 や振幅 ${ }^{18,19)}$ は, 入浴群の方が回復量が大きくなって いる.これは沖田が21) 言う認知情報処理過程の強度 や注意水準が入浴の温熱効果により向上したためと考 えられる，以上により，VDT 作業によって誘発され た精神疲労の回復に入浴は有効であると推察でき,こ れらは $38^{\circ} \mathrm{C}$ 微温浴が精神疲労の回復によい言われ ている2,20)こととほほ一致する。

リラックス感や覚醒の指標と考えられている自発脳 波から算出される $\alpha$ 波帯域のパワーに関しては，入 浴条件と非入浴条件で回復の程度に統計的な差異は認 められなかった，すなわち，入浴条件と安静条件とで 差のあった精神疲労感を評価するには, 従来の自発脳 波のスペクトル解析よりも事象関連電位の振幅や潜時 の方がより適切であると思われる。

\section{5. 結 論}

入浴の疲労回復効果を事象関連電位と主観の計測に より, 入浴と安静だけの非入浴条件とを比較しながら 評価を行った。暗算作業終了後, 入浴条件では, 安静 のみの非入浴条件に比べ, 精神疲労感は有意に回復 し, 生理計測では事象関連電位の振幅が有意に回復し た。被験者は 6 名での条件ではあるが, これらの結果 を総合して考えると, 微温浴の入浴には, 安静のみの
疲労回復法より精神疲労を回復させる効果が高いと考 えられる.また， $\alpha$ 波のパワーやピーク周波数 \pm 1.0 $\mathrm{Hz}$ のパワーよりも事象関連電位の振幅や潜時が精神 疲労の評価に有効であることも示唆された. 今後は, 被験者数を増加させるとともに，脳波の計測だけでな く, 心拍関係の測定も同時に行いながら，入浴の効果 を多角的に解明していきたいと考えている。また，入 浴条件なども変えながら入浴の持つ効果を詳細に検討 していきたいと考えている.

\section{謝 辞}

この研究を推進するに当たり, 計画, 実験, 解析の 多岐にわたり協力, ご助言して下さった積水化学工業 (侏の高沢氏，大塚氏ならびに日本健康開発財団の矢崎 氏，後藤氏に深く感謝いたします。なお，本研究は通 商産業省・工業技術院の産業科学技術研究開発プロジ エクト「人間感覚計測応用技術」の一環として, 新エ ネルギー・産業技術総合開発機構（NEDO）からの 委託により, 社団法人人間生活工学研究センター （HQL）を通して行われたものである.

\section{参考文献}

1）大西徳明, 岡 智子, 田実睦美：入浴による姿勢 保持筋群の疲労回復に関する研究，労働科学， 67 (7) , 323-337, 1991.

2) 植田理彦：入浴の科学一健康への効果, フレグ ランスジャーナル, (69), 6-10, 1984.

3）田中信彦：入浴の生理学, フレグランスジャー ナル, (69), 11-16, 1984.

4）古元嘉昭：1 入浴の医学, 香粧会誌, $10(4), 226$ 228, 1986.

5）藤田 勉：これからの温泉医療研究のあるべき 姿, 温泉科学, 40, 136-140, 1990.

6）菅井芳郎, 白倉卓夫：微温長時間による成長木 ルモンの反応，医学と生物学，108(3)，149-152, 1984.

7）妹尾敏伸：温泉浴の生理機能に及ほす影響 第 II編 血獎副腎皮質ホルモン值に及ほす温泉浴の 影響, 日温気物医誌, 49(4), 181-186, 1986.

8) Kanda, K. Tsuchida, J. Seto, M. Ohnaka T. \& Tochihara Y.: Thermal Conditions in the bath room in Winter and Summer and Physiological Responses of the Elderly during Bathing, Japan Journal of Hygiene, 50, 595-603, 1995.

9）伊藤不二夫, 藤原敏雄, 長井克介, 川崎義巳 $: 3$. バスクリン浴による主観的自覚症状 寛解の数量 的多変量解析，日温気物医誌， $50(3) ， 147-157$, 
1987.

10) Gauer, O. H.: Diehydrostatische Wirkung von Baedern auf denkreislauf, Dtsch Medical Journal, 6, 462, 1955.

11) Rowell, L. B. : Human cardiovascular adjustment to exercise and thermal stress, Physiology Review, 54, 75-159, 1974.

12）徳竹忠司, 佐々木公一, 吉川恵士, 淺井克晏, 乾 全良, 石田隆男, 新井清一, 松田誠司: 朝鮮人参工 キス入り入浴剤の循環動態に及ほす影響, 日温気 物医誌, 55(4), 195-205, 1992.

13）垣鐸 直, 二和田篤, 金子堅三, 里見泰彦：酸素 による気泡浴が人体に及ほす影響, The Annals of Physiological Authropology, 8(1), 21-24, 1989.

14）服部正明, 内野欽司, 森本 茂, 村松浩一郎：研 究発表 15 入浴剤による体温調節機構への影響 について, 第 9 回人間一熱環境系シンポジウム報 告集, 70-73, 1985.

15）矢永尚士, 武居光雄, 牧野直樹, 藤原敏雄, 渡邊 智: 精神性発汗測定による人工温泉浴の脱ストレ ス作用の検討, 日温気物医誌, 61, 202, 1998.

16) Yabunaka N.: Influence of size of bath on the appearance of $\alpha$ waves in electroencephalograms during bathing, J. J. A. Phys, M. Baln. Clim, 59, 105, 1996.

17）木内妙子, 大塚修子, 塩津三四子, 恒成和美：温 水浴の生体機能に及ぼす影響, 学芸紀要（自然）,
34, 69-79, 1983.

18）村田厚生：ヒューマン・インターフェイス設計 に関する基礎検討, 日産科学振興財団研究報告書, 14, 181-187, 1991.

19) Uetake A. \& Murata A. : Assessment of Mental Fatigue during VDT Task using Eventrelated Potential (P 300), Proceedings of the 2000 IEEE International Workshop on Robot and Human Interactive Communication, 235240, Osaka, Japan, 2000.

20）橋本邦衛，安全人間工学，中央労㗢災害防止協 会, 1986.

21）植竹篤志, 松本修一郎, 海老澤美保 : 疲労・疲労 回復評価技術の開発, 人間感覚計測応用技術の研 究開発研究報告書, 第 2 分冊, 406-430, 1993.

22）植竹篤志, 松本修一郎, 海老澤美保 : 入浴環境下 における快適性の評価技術の研究開発, 人間感覚 計測応用技術の研究開発研究報告書, 第 1 分冊, 285-423, 1994.

23）日本温泉気候物理医学会編, 入浴 - 温泉療養又 ニュアル, 8, 1999.

24）沖田庸嵩：ERP 研究に役立つ心理実験パラダ イム ( I )，臨床脳波，34，269-275, 1992.

25）下河内稔：事象関連電位(II)，臨床脳波，23 (11), 743-752, 1981.

26）沖田庸嵩：ERP 研究に役立つ心理実験パラダ イム(II)，臨床脳波, 34, 334-339, 1992. 